Marek Daniel KOWALSKI

Uniwersytet Jagielloński

\title{
Nieznany dokument papieski dla Andrzeja, pierwszego biskupa Seretu i Wilna, i powstanie biskupstwa wileńskiego
}

Młode biskupstwa na wschodzie monarchii Jagiellonów, ufundowane na obszarach zamieszkałych przez niewielką liczbę katolików, mają dość ubogą dokumentację źródłową dotyczącą ich najstarszych dziejów ${ }^{1}$. Nowe diecezje powstawały w czasie, gdy decydujący głos — patrząc od strony formalnej w rozbudowie organizacji kościelnej należał do Stolicy Apostolskiej, więc podejmowane działania powinny znajdować odbicie w źródłach proweniencji papieskiej. Archiwa papieskie (obediencji rzymskiej) z okresu schizmy zachodniej (1378-1417) poniosły jednak bardzo poważne straty i ocalały zasób źródeł jest relatywnie niewielki. Z czasów papieża Urbana VI (1378-1389) nie zachował się ani jeden tom registrów kancelaryjnych z najważniejszej serii Registra Lateranensia ${ }^{2}$. Archiwum Watykańskie zostało już dokładnie przejrzane przez polskich historyków w poszukiwaniu poloników. Dokumenty papieskie wykorzystał Władysław Abraham w swoich pracach na temat biskupstw metropolii lwowskiej (w tym także biskupstwa mołdawskiego) ${ }^{3}$ oraz ks. Jan Fijałek i Władysław Semkowicz w odniesieniu do biskupstwa wileńskiego ${ }^{4}$. W późniejszym czasie kwerendę w zasobie Archivum Secretum Vaticanum na potrzeby swoich edycji źródłowych przeprowadzili Edmund Długopolski ${ }^{5}$ oraz Stanisław i Irena Kurasiowie ${ }^{6}$. W tak dokładnie przejrzanym zasobie udało się jednak znaleźć kolejny nieznany dokument papieski przy okazji prowadzonej przeze mnie kwerendy na potrzeby wydawnictwa źródłowego Monumenta Vaticana res gestas Polonicas illustrantia (lata 1378-1503).

Użyte w tytule określenie „nieznany dokument” nie jest do końca ścisłe. O istnieniu omawianej tu bulli wiadomo bowiem historykom już od blisko 100 lat, ale znano tylko pierwszych 8 wierszy jej tekstu. W praktyce znany był więc tylko wystawca dokumentu (papież Bonifacy IX) oraz jego adresat

\footnotetext{
1 W artykule wykorzystano materiały zebrane podczas realizacji grantu NPRH pt. „Monumenta Vaticana res gestas Polonicas illustrantia — edycja źródeł proweniencji papieskiej do dziejów Polski w późnym średniowieczu (od 1394 roku)”. (projekt nr 11H 120301 81), realizowanego w Instytucie Historii PAN.

${ }^{2}$ Wyjątkiem jest ocalały niewielki fragment jednego z registrów, zob. P. Zutshi, Unpublished Fragments of the Registers of Common Letters of Pope Urban VI (1378), w: Kurie und Region. Festschrift für Brigide Schwarz zum 65. Geburtstag, hrsg. von B. Flug, M. Matheus, A. Rehberg, Stuttgart 2005, s. 41-61. Z czasów Urbana VI zachowały się ponadto dwa (i fragment trzeciego) tomy z serii Registra Vaticana, ale są tam bulle innej natury, por. Archivum Secretum Vaticanum [dalej: ASV], Reg. Vat., vol. 310-312.

3 W. Abraham, Biskupstwa tacińskie w Mołdawii w wieku XIV i XV, Kwart. Hist., 16, 1902, z. 2, s. 172-207; tenże, Powstanie organizacji Kościoła łacińskiego na Rusi, t. 1, Lwów 1904.

${ }^{4}$ Odnalezione bulle zostały zamieszczone w edycji źródłowej: Kodeks dyplomatyczny katedry i diecezji wileńskiej, t. 1, wyd. J. Fijałek i W. Semkowicz, Kraków 1932 [dalej: KDWil].

5 Monumenta Poloniae Vaticana, t. 8/1, ed. E. Długopolski, Kraków 1939-1946.

${ }^{6}$ Bullarium Poloniae, t. 3 (1378-1417), ed. I. Sułkowska-Kuraś et S. Kuraś, Romae-Lublini 1988.
} 
(Andrzej, biskup Seretu), bez żadnych dalszych szczegółów, tak więc bulla nie przedstawiała żadnej wartości dla badaczy. Informacja o dokumencie znalazła się w przywoływanych wyżej edycjach źródłowych. E. Długopolski słusznie umieścił go wśród bulli z pierwszego roku pontyfikatu Bonifacego IX ${ }^{7}$, a S. Kuraś uznał go po prostu za niedatowany dokument tegoż papieża z lat 1389-13948.

Kopia bulli dla Andrzeja, biskupa mołdawskiego, została pierwotnie wpisana do jednego z tomów registrów Kancelarii Apostolskiej, obecnie stanowiącego piąty tom serii Registra Lateranensia. Karta, na której znajduje się początek dokumentu, została jednak wyrwana i trafiła do tomu nr 2463 tego samego zespołu9. Ten ostatni rękopis nie jest jednak typowym registrem kancelaryjnym, ale sztucznie stworzonym zbiorem rozmaitych fragmentów, luźnych kart i składek, pochodzących z różnego czasu, w tym także z pontyfikatu papieża Bonifacego IX. Tam właśnie kartę z początkiem bulli znaleźli polscy wydawcy. Podczas kwerend nie zauważono natomiast, że pozostała część dokumentu (85\% tekstu) zachowała się do dziś na swoim pierwotnym miejscu ${ }^{10}$. Przeoczenie to łatwo zrozumieć, gdyż po wyrwaniu karty pozbawiony początku ,polski” tekst wydawał się po prostu dalszym ciągiem poprzedzającej bulli, adresowanej do konwentu św. Gertrudy w Nivelles (diecezja Liège), której zakończenie znalazło się oczywiście również na wyrwanej karcie. Tak więc pierwsza część interesującego nas dokumentu znajduje się obecnie w tomie nr 2463, a druga w tomie nr 5 Registrów Laterańskich. Tego, że chodzi tu o dwie części jednej bulli, dowodzi bez żadnych wątpliwości zarówno ciągłość tekstu, jak i zachowana oryginalna foliacja ${ }^{11}$.

Omawiany dokument papieski adresowany jest do Andrzeja, biskupa Seretu, czyli do Andrzeja h. Jastrzębiec, pierwszego katolickiego ordynariusza Mołdawii. Wystawiony został przez papieża Bonifacego IX (1389-1404), ale odnosi się do łaski przyznanej jeszcze przez poprzednika na Piotrowym tronie. Niegdyś bowiem, za pontyfikatu Urbana VI (1378-1389), ze względu na ubóstwo swojego biskupstwa Andrzej otrzymał zgodę na kumulowanie z biskupstwem sereckim kościoła parafialnego w Kłodawie (będącego już w posiadaniu Jastrzębca) i jeszcze jednego dodatkowego beneficjum kościelnego, jeśli jakieś zdoła objąć w przyszłości. Kancelaria Apostolska wystawiła w tej sprawie stosowną bullę. Jakiś czas później Andrzej zwrócił się do Stolicy Apostolskiej o korektę błędu, jaki znalazł się w papieskim dokumencie, gdyż - jak podał w suplice - w bulli z dyspensą, jako posiadane beneficjum omyłkowo wpisano kościół w Kłodawie, zamiast prepozytury kaliskiej. Jak zawsze w takich przypadkach petent prosił też, by dokument zachował ważność tak, jakby od początku zawarte w nim były właściwe dane. Suplika została pozytywnie rozpatrzona przez Urbana VI dnia 20 II 1386 r., ale Andrzej nie zadbał o wystawienie dokumentu przed śmiercią papieża, który zmarł 15 X 1389 r. Dopiero w omawianej tu bulli z 9 XI 1389 r. Bonifacy IX potwierdził decyzję swojego poprzednika i jej ważność od daty supliki, czyli od dnia 20 II 1386 r. Przy okazji w dokumencie papieskim podano, niewątpliwie na podstawie supliki, że dobra biskupstwa mołdawskiego zostały spustoszone przez niewiernych (!) Litwinów, Andrzej ogłosił w swej diecezji wyroki wydane przez Urbana VI przeciw antypapieżowi Klemensowi VII oraz, iż biskup ten nawrócił i ochrzcił jakiegoś księcia i 300 osób $^{12}$.

W bulli z 9 XI 1389 r. kancelaria papieska zastosowała formularz z następującą arengą: „Rationi congruit et convenit honestati, ut ea que de Romani pontificis gratia processerunt, licet eius superveniente obitu super illis littere apostolice confecte non fuerint, suum consequantur effectum"13. Formularz „Rationi” stosowano w przypadku, gdy suplika została pozytywnie rozpatrzona przez papieża,

\footnotetext{
MPV, t. 8, nr 85.

8 Bull. Pol., t. 3, nr 398.

9 ASV, Reg. Lat., vol. 2463, f. 2 r.

${ }_{10}$ ASV, Reg. Lat., vol. 5, f. 10r-10v.

${ }^{11}$ Karta z początkiem bulli ma numer „X” oryginalnej rzymskiej foliacji (Reg. Lat., vol. 2463, f. 2v), a karta z dalszym ciągiem dokumentu ma numer „XI” (Reg. Lat., vol. 5, f. 10r).

12 Pełny tekst bulli z 9 XI 1389 wydany jest na końcu niniejszego artykułu.

${ }^{13}$ Czasem arenga ma minimalnie zmienioną formę: „Rationi congruit et convenit equitati...”.
} 
ale przed jego śmiercią odnośna bulla nie została wystawiona przez kancelarię. Biorąc pod uwagę fakt, że niekiedy między zatwierdzeniem supliki a ekspedycją dokumentu mijało kilka miesięcy lub nawet lat (jak właśnie w omawianym przypadku), sytuacje takie nie były rzadkością. Należy pamiętać, że zasadniczo bulla nosiła datę supliki (czyli datę papieskiej decyzji), ale z oczywistych powodów nie mogła zostać wystawiona pod imieniem i pieczęcią następnego papieża. Aby nie zmuszać petenta do ponownego składania prośby w tej samej sprawie, wystawiane były właśnie bulle typu „Rationi”. Zaraz na wstępie dokumentu znajdowała się informacja, że chodzi tu o potwierdzenie łaski przyznanej przez poprzednika na Piotrowym tronie, z podaniem daty supliki, a potem w treści znajdowało się wszystko to, co miało się znaleźć w dokumencie poprzednika. Ważność udzielonej łaski liczyła się od daty supliki.

Bulle „Rationi” wystawiano zawsze z datą pierwszego dnia pontyfikatu nowego papieża, a więc pismo dla biskupa Andrzeja Jastrzębca nosi datę 9 XI 1389 r. ${ }^{14}$ Nie znaczy to jednak, że faktycznie wtedy zostało ono wyekspediowane. W omawianym przypadku można stwierdzić z całą pewnością, że stało się to dopiero kilka miesięcy później. Tekst bulli wpisany jest na pierwszej składce piątego tomu Registrów Laterańskich ${ }^{15}$. Wśród poprzedzających ją dokumentów większość stanowią bulle typu „Rationi”, a więc noszące datę 9 XI 1389 r., ale pomiędzy nimi znajduje się bulla z $29 \mathrm{~V}$ $1390 \mathrm{r}^{16}, \mathrm{a}$ - co ważniejsze - na tej samej karcie, na której rozpoczyna się dokument dla Andrzeja Jastrzębca, wpisano bullę z $30 \mathrm{~V} 1390 \mathrm{r} \cdot{ }^{17} \mathrm{Z}$ kolei bezpośrednio po nim, jeszcze na tej samej karcie, jest bulla z $20 \mathrm{X} 1390 \mathrm{r}^{18}$ Jak widać, bulla dla biskupa mołdawskiego musiała zostać wystawiona po $30 \mathrm{~V} 1390$ r., zaś dokument wyznaczający terminus ante quem został wystawiony i wpisany do registru jakiś czas po 20 października tego samego roku.

Omówiona wyżej treść dokumentu Bonifacego IX dla Andrzeja Jastrzębca jest dość banalna. Udzielanie dyspensy ubogim biskupom na posiadanie (a ściślej objęcie w komendę) dodatkowego beneficjum niższego, które miało stanowić podstawę ich utrzymania, było praktyką powszechną. Dotyczyło to przede wszystkim biskupów tytularnych, a w przypadku Polski także ordynariuszy wschodnich diecezji Królestwa ${ }^{19}$. Ze względu na fakt, iż z zasady biskupstwa nie wolno było łączyć z żadnym innym beneficjum kościelnym, dyspensy na tego typu kumulację musiała zawsze udzielić Stolica Apostolska. Andrzej Jastrzębiec również otrzymał podobne pozwolenie niedługo po objęciu katedry w Serecie. Na suplikę królowej Elżbiety Łokietkówny, Grzegorz XI zezwolił mu bullą z 23 VII 1372 r. objąć w komendę jedno dowolne beneficjum i posiadać je, dopóki będzie biskupem mołdawskim, nawet dożywotnio ${ }^{20}$. Niewątpliwie mocą tej dyspensy Andrzej objął kościół parafialny w Kłodawie. Jak informuje omawiana tu bulla Bonifacego IX, przed dniem 20 II 1386 r. Jastrzębiec uzyskał kolejną dyspensę papieską na kumulowanie drugiego beneficjum, oprócz dzierżonej już wtedy plebanii kłodawskiej. Ani oryginał tej bulli, ani kopia - z powodu zniszczenia wszystkich registrów kancelaryjnych z czasów Urbana VI — nie zachowały się do dzisiaj. Nie wiadomo też, jaką nosiła ona datę. Pisarz papieski podał, że był to dzień 20 II 1386 r., ale trzeba uznać to za pomyłkę. Można tylko przypuszczać, że wystawiono ową bullę niezbyt długo przed 20 II 1386 r., kiedy to papież rozpatrzył suplikę o jej korektę.

\footnotetext{
${ }_{14}$ T. Frenz, I documenti pontifici nel medioevo e nell'età moderna, wyd. 2, Città del Vaticano 1998, Littera antiqua 6, s. 44.

15 Składka ta obejmuje folia $1-22$ (wg obecnej numeracji). Wprawdzie karta z początkiem bulli dla Andrzeja Jastrzębca została wyrwana, ale druga połowa tego bifolium (dziś f. 14) została na swoim miejscu, przyklejona do bloku składki. Ponadto na początku składki doklejono kartę (obecnie f. 1), więc składka ma dziś parzystą liczbę kart.

${ }^{16}$ ASV, Reg. Lat., vol. 5, f. 5v-6r.

17 ASV, Reg. Lat., vol. 2463, f. 2v-2r. Karta została wklejona do tomu odwrotnie, więc początek bulli jest na stronie 2v, a zakończenie na $2 \mathrm{r}$.

18 ASV, Reg. Lat., vol. 5, f. 10v. Dalej są znowu 3 bulle „Rationi” (f. 10v-13v).

19 Por. np. KDWil, nr 102, 103; Bull. Pol., t. 4, nr 2150; Bull. Pol., t. 6, nr 1837; Bull. Pol., t. 7, nr 580, 711; MPV, t. 10, nr 740, $755,817,838,839,864,1012,1016$.

${ }^{20}$ Bullarium Franciscanum sive Romanorum pontificum costitutiones, epistolae, diplomata..., t. 6, ed. C. Eubel, Romae 1902, nr 1212; reg. w: Bull. Pol., t. 2, nr 1953.
} 
Prośby o wystawienie pisma korygującego informacje w wyekspediowanym dokumencie papieskim również co jakiś czas się zdarzały, najczęściej bodajże dotycząc błędnie podanych wartości beneficjów. W omawianym przypadku nie ma zresztą pewności, że wpisanie do bulli kościoła w Kłodawie było zwykłym błędem prokuratora spisującego suplikę. Prawdopodobnie w czasie, gdy trwało załatwianie sprawy w Kurii Rzymskiej (jeszcze przed przyznaniem dyspensy na kumulowanie drugiego beneficjum niższego), Andrzej otrzymał prepozyturę kaliską. Nie mógł jej zatrzymać razem z Kłodawą, gdyż plebania i prałatura były beneficjami niekompatybilnymi, musiał więc opuścić kościół w Kłodawie. Aby uniknąć ponownego składania supliki z prośbą o potwierdzenie zamiany beneficjów, sprawę załatwiono trybem korekty wydanej już bulli.

Jeśli sprawy będące przedmiotem bulli z 9 XI 1389 r. są typowe, to użyta w powyższym dokumencie tytulatura Andrzeja Jastrzębca w odniesieniu do 1390 r. stoi w sprzeczności z powszechnie przyjętymi w historiografii poglądami na chronologię obsady biskupstwa wileńskiego i mołdawskiego. Uważa się bowiem, że około połowy 1388 r. kanonicznie erygowane zostało biskupstwo w Wilnie, a jego pierwszym ordynariuszem został Andrzej Jastrzębiec, zwalniając tym samym dzierżoną dotąd katedrę w Serecie. Tak więc adresat bulli był już od ponad dwóch lat biskupem wileńskim, a nie sereckim. By zbliżyć się do wyjaśnienia tej zagadki trzeba przyjrzeć się poglądom historyków na temat początków biskupstwa wileńskiego i mołdawskiego oraz krytycznie ocenić źródła, na których się opierali.

Adresat bulli, Andrzej h. Jastrzębiec, pierwszy biskup mołdawski, a później pierwszy biskup wileński, jest postacią dobrze znaną historiografii. Pochodził z Małopolski, ze szlacheckiej rodziny herbu Jastrzębiec ${ }^{21}$. Wstąpił do zakonu franciszkanów, stąd też nazywany bywał Andrzejem z Krakowa, od miasta, w którym znajdował się jego macierzysty konwent. Działał jako kaznodzieja na Mazowszu (1354 r.), potem prawdopodobnie jako misjonarz na Litwie, wreszcie został spowiednikiem królowej węgierskiej Elżbiety Łokietkówny. Z jej poparciem 31 VII 1370 r. otrzymał papieską desygnację na pierwszego ordynariusza nowopowstałego biskupstwa w Serecie w Mołdawii. Konsekrowany został w Krakowie wiosną następnego roku i prawdopodobnie przez pewien czas działał w swojej diecezji. Zapewne z powodu niekorzystnych dla Kościoła katolickiego zmian politycznych w Mołdawii musiał na stałe opuścić swoje biskupstwo. W latach 1376-1388 poświadczony jest w roli biskupa pomocniczego w archidiecezji gnieźnieńskiej. Być może uczestniczył w wyprawie chrystianizacyjnej Jagiełły na Litwę w 1387 r. Kolejnym etapem jego kariery była translacja na biskupstwo w Wilnie, którego został pierwszym ordynariuszem. Andrzej zmarł 14 XI 1398 r. ${ }^{22}$

W literaturze przedmiotu pojawiają się różne daty utworzenia biskupstwa wileńskiego i przeniesienia Andrzeja Jastrzębca z Seretu do Wilna. Podawane są lata 1386, 1387 (za Długoszem) lub 1388. Narosło przy tym trochę błędów, które warto w tym miejscu sprostować. W swoim zestawieniu katolickich hierarchów (z 1873 r.) Pius Bonifacius Gams podał, że Andrzej opuścił biskupstwo mołdawskie i objął wileńskie w 1386 roku $^{23}$. Zgodnie z charakterem swej pracy nie przywołał żadnych źródeł, ale zapewne kierował się w tym przypadku po prostu datą chrztu Jagiełły. Dzieło Gamsa można by potraktować jako egzotyczne, niezbyt interesujące $\mathrm{z}$ polskiego punktu widzenia, ale z niego informacja ta trafiła do szeroko wykorzystywanego aż po dziś dzień wykazu Konrada Eubla Hierarchia Catholica medii aevi ${ }^{24}$. Wprawdzie w wykazie poprawek w drugim wydaniu (1914 r.) K. Eubel zamie-

\footnotetext{
${ }^{21}$ M. Sepiał, Krag rodzinny Andrzeja herbu Jastrzębiec biskupa Wilna 1388-1398, „Zeszyty Naukowe Uniwersytetu Jagiellońskiego. Prace Historyczne”, 128, 2001, s. 71-78.

${ }^{22}$ Informacje biograficzne o Andrzeju Jastrzębcu nie opatrzone przypisami pochodzą z biogramów: K. Pieradzka, Andrzej (+1398), franciszkanin, (...) biskup sereteński, pierwszy biskup wileński, PSB, t. 1, Kraków 1935, s. 102-103; K. Prokop; Biskupi pomocniczy $w$ diecezjach polskich $w$ dobie przedtrydenckiej, Kraków 2002, s. 189-191; W. Abraham, Powstanie organizacji, s. 285-287; P. Czaplewski, Tytularny episkopat w Polsce średniowiecznej, „Roczniki Towarzystwa Przyjaciół Nauk Poznańskiego", t. 40, 1913, s. 139-143.

${ }^{23}$ P.B. Gams, Series episcoporum Ecclesiae Catholicae, Regensburg 1873-1886, s. 360 i 365.

${ }^{24}$ C. Eubel, Hierarchia Catholica medii aevi, t. 1 (1198-1431), wyd. 2, Monasterii 1913, s. 182, 529.
} 
ścił wiadomość, że do 1388 r. Andrzej notowany jest jako biskup pomocniczy w diecezji gnieźnieńskiej, co automatycznie przesunęło moment przejścia do Wilna o dwa lata, ale informacja ta umyka użytkownikom jego dzieła ${ }^{25}$. K. Eubel wprowadził do obiegu naukowego kolejną błędną informację w swojej edycji źródłowej Bullarium Franciscanum. W jednym z przypisów wskazał na rękopis Kamery Apostolskiej, zawierający obligacje serwicjalne biskupów z okresu pontyfikatu Urbana VI, w którym znalazł licznych biskupów z zakonu franciszkanów i jako pierwszego wymienił Andrzeja Wasilo, który miał zostać przeniesiony z Seretu do Wilna „około 1386 r.”26. W rzeczonym rękopisie obligacji Jastrzębca jednak nie ma, a powyższa informacja jest efektem pomyłki ${ }^{27}$. W ten sposób błędna wiadomość, zaczerpnięta kiedyś od P.B. Gamsa, nabrała waloru źródłowego ${ }^{28}$. Z tego powodu Paweł Czaplewski w swoim solidnym biogramie pierwszego biskupa mołdawskiego uznał, iż Andrzej uzyskał prowizję na biskupstwo wileńskie już w 1386 roku, ale dyplomacja krzyżacka aż przez dwa lata wstrzymywała jej ekspedycję ${ }^{29}$. Ewidentnie błędna data 1386 roku do dziś pojawia się czasem w opracowaniach poświęconych obsadzie biskupstw w Wilnie i Serecie ${ }^{30}$.

Opierając się na materiale źródłowym z archiwum katedry wileńskiej, większość historyków zgodnie przyjmuje, że kanoniczne erygowanie biskupstwa wileńskiego i translacja Andrzeja Jastrzębca $\mathrm{z}$ Seretu do Wilna dokonały się $\mathrm{w}$ drugiej połowie $1388 \mathrm{roku}^{31}$. Podstawą do takiego twierdzenia jest, znana tylko z insertu, bulla Urbana VI z 12 III 1388 r., w której papież polecił biskupowi poznańskiemu Dobrogostowi z Nowego Dworu, by oficjalnie powołał do życia nową diecezję i mianował biskupa Seretu Andrzeja na jej pierwszego ordynariusza, po uprzednim stwierdzeniu, czy spełnione są wszystkie warunki do fundacji biskupstwa na Litwie. Drugim źródłem jest niedatowane pismo tegoż Dobrogosta (zawierające inserowaną bullę Urbana VI), informujące o wprowadzeniu w życie

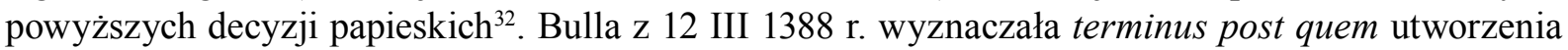
biskupstwa w Wilnie i translacji Andrzeja Jastrzębca, a za oczywiste uznawano, że wprowadzenie jej postanowień w życie nastąpiło niezwłocznie po przywiezieniu papieskiego dokumentu do kraju. Należy przy tym podkreślić, iż sprawie chronologii objęcia biskupstwa wileńskiego przez Andrzeja nie poświęcano zbyt wiele uwagi, gdyż nie wydawała się ona dyskusyjna.

Tytulatura Andrzeja w bulli wyekspediowanej w drugiej połowie 1390 r. nie zgadza się więc z ustaloną opinią historiografii. Autentyczność papieskiego dokumentu nie może jednak budzić najmniejszej wątpliwości, gdyż jego kopia znajduje się urzędowych księgach Kancelarii Apostolskiej. Wykluczyć należy też pomyłkę kancelarii co do osoby lub tytułu adresata. Wprawdzie pomyłki w registrach, nie-

\footnotetext{
${ }^{25}$ C. Eubel, Hierarchia Catholica medii aevi, t. 2 (1431-1503), wyd. 2, Monasterii 1914, „Addenda et emendanda ad volumen I", s. XX.

${ }^{26}$ Bullarium Franciscanum sive Romanorum pontificum costitutiones, epistolae, diplomata..., t. 7 [1378-1431], ed. C. Eubel, Romae 1904, s. 7, przyp. 3.

${ }^{27}$ Rękopis ten przechowywany jest obecnie pod sygnaturą ASV, Cam. Ap., Oblig. et Sol., vol. 48. Na pomyłkę Eubla wskazuje już samo stwierdzenie, że Andrzej Jastrzębiec złożył obligację „około 1386” (c. 1386), podczas gdy zapiski obligacyjne zawsze zawierają datę dzienną. Takie też dokładne daty Eubel podał przy kolejnych wyliczanych biskupach-franciszkanach. ${ }^{28}$ Przy okazji źródłowe ,potwierdzenie” zyskał przydomek, „Wasilo”.

${ }^{29}$ P. Czaplewski, Tytularny episkopat, s. 143. Rozumowanie autora jest w tym przypadku całkowicie błędne i wynika z niewłaściwej interpretacji informacji podanych przez K. Eubla w Hierarchia Catholica oraz z nieznajomości procedury ekspedycji dokumentów papieskich, bowiem złożenie obligacji serwicjalnej następowało już po wyekspediowaniu bulli.

${ }^{30}$ P. Nitecki, Biskupi Kościoła w Polsce w latach 965-1999. Stownik biograficzny, Warszawa 2000, s. 20 (z tego biogramu błędna informacja trafiła do popularnej Wikipedii: http://pl.wikipedia.org/wiki/Jan_(biskup_serecki) [dostęp: 8.04.2015]). Z kolei K. Prokop podaje (bez wskazania źródła), że Jan Sartoris, następca Andrzeja Jastrzębca na biskupstwie w Serecie, został wysunięty na tę godność w 1386 r. (choć objął ją dopiero w 1388 r.), co automatycznie oznacza, że już w 1386 r. Andrzeja wysunięto na biskupstwo w Wilnie, zob. K. Prokop; Biskupi pomocniczy, s. 233-234.

${ }^{31}$ W. Abraham, Biskupstwa łacińskie, s. 179-184; J. Fijałek, Uchrześcijanienie Litwy przez Polske i zachowanie w niej języka ludu, w: Polska i Litwa w dziejowym stosunku, Kraków 1914, s. 64-66; K. Pieradzka, Andrzej (+1398), s. 102-103. Najnowszy i najobszerniejszy jest biogram w: K. Prokop, Biskupi pomocniczy, s. 189-191, ale autor ten nie przeprowadza krytycznej analizy źródeł, a biogramy w książce zawierają tylko kompilację informacji pochodzących ze źródeł i literatury. ${ }^{32}$ KDWil, nr 10, 13. Nieco dalej dokładnie omawiam powyższe źródła.
} 
kiedy bardzo poważne ${ }^{33}$, zdarzały się czasem, ale były wychwytywane podczas kontroli i w księdze dokonywano stosownych poprawek lub kasowano wpis i ponownie wpisywano poprawną wersję ${ }^{34}$. Zgodnie z procedurą, bulla musiała zostać wyekspediowana z inicjatywy Andrzeja Jastrzębca. Gdyby zasiadał on już wtedy w Wilnie, błędne określenie adresata mianem biskupa Seretu spowodowałoby nieważność dokumentu. Pomyłkę tego rodzaju z pewnością od razu dostrzegłby odbierający bullę pełnomocnik Andrzeja. Sporządzono by wtedy nowy oryginał i dokonano korekty wpisu w registrze. Wykluczyć też należy możliwość, że oryginał bulli był adresowany: „Andree episcopo Wilnensi”, a jedynie w registrze kancelaryjnym znalazł się pomyłkowo nieaktualny tytuł biskupa mołdawskiego, wzięty z supliki z 1386 r. Najprawdopodobniej bowiem kopie w registrze były odpisywane z orygina$\mathrm{lu}^{35}$, a taki błąd $\mathrm{w}$ adresie zostałby bez trudu wychwycony podczas kontroli i skorygowany. Poza tym bulla z dyspensą dla biskupa wileńskiego, by mógł kumulować beneficja niższe z (opuszczonym już) biskupstwem w Serecie byłaby zwyczajnie pozbawiona sensu ${ }^{36}$. W grę nie wchodzi wreszcie pomyłka w dacie dokumentu papieskiego, której z oczywistych powodów nie da się cofnąć na rok 1388 lub wcześniejszy. Należy więc przyjąć, że w połowie 1390 r. Andrzej Jastrzębiec ciągle jeszcze był biskupem mołdawskim. W tej sytuacji trzeba krytycznie przyjrzeć się źródłom, mówiącym o utworzeniu biskupstwa w Wilnie.

Obsada biskupstwa mołdawskiego jest tak słabo udokumentowana źródłowo, że nie może być pomocna w ustaleniu daty przejścia Andrzeja Jastrzębca na katedrę wileńską. O jego następcy, niejakim Janie Sartoris, nie wiemy niemal nic. W szczególności nie znamy prowizji papieskiej na biskupstwo w Serecie, nie ma też o nim żadnej wzmianki w aktach Kamery Apostolskiej. Imię następcy Andrzeja wspomniane jest dopiero w prowizji dla kolejnego ordynariusza mołdawskiego, dominikanina Stefana syna Marcina. Bullą z 8 VI 1394 roku Bonifacy IX powierzył mu biskupstwo w Serecie, wakujące po śmierci Jana ${ }^{37}$. Znany jest ponadto jeden niedatowany dokument odpustowy wystawiony przed 1405 r. przez Jana, biskupa Seretu i sufragana krakowskiego, który potwierdza istnienie biskupa mołdawskiego o tym imieniu, ale niczego nie wnosi do chronologii ${ }^{38}$. Podawane $w$ literaturze daty początkowe pontyfikatu Jana Sartoris, a więc rok 1386 lub 1388, nie mają bezpośredniego oparcia w źródłach, ale zawsze za punkt wyjścia przyjmują domniemany moment przeniesienia Andrzeja Jastrzębca do Wilna.

Choć pierwsze litewskie biskupstwo powstało pod koniec XIV wieku, to wbrew temu, czego można by oczekiwać, podstawa źródłowa i w tym przypadku jest dość skromna. Jest rzeczą oczywistą, że zamysł utworzenia organizacji kościelnej na Litwie musiał zrodzić się równocześnie z decyzją o przyjęciu chrztu przez Władysława Jagiełłę. Chrzest miał miejsce 15 II 1386 r. i wkrótce potem król podjął kroki zmierzające do powołania diecezji na chrystianizowanych obszarach. Obowiązkiem monarchy,

\footnotetext{
${ }^{33}$ Zdarzają się błędy wskazujące na to, że pisarz musiał mieć przed sobą dwie różne bulle, dotyczące tej samej sprawy (tego samego beneficjum) i podczas wpisywania do registru pomieszał ich treść, ale w omawianym przypadku nic na to nie wskazuje. Poza tym i tak błąd wyłapałaby kontrola.

${ }^{34}$ Paradoksalnie, jak wcześniej wspomniałem, w omawianej bulli najpewniej błędnie podano datę dyspensy na kumulowanie parafii w Kłodawie i drugiego beneficjum z biskupstwem w Serecie, ale tego rodzaju błąd był dużo trudniejszy do wykrycia, niż pomyłka w tytulaturze adresata bulli.

${ }^{35}$ Uważa się, że wpisy w Registrach Laterańskich były dokonywane na podstawie przygotowanego już oryginału dokumentu, w przeciwieństwie do wpisów w Registrach Watykańskich, które sporządzano na podstawie minuty bulli, choć niektórzy dyplomatycy mają w tej sprawie odmienne zdanie, zob. T. Frenz, I documenti pontifici, s. 56. Gdyby nawet za pontyfikatu Bonifacego IX wpisy opierały się na minutach dokumentów, to i tak nie zmienia to sytuacji. Podczas kontroli bez trudu wyłapano by różnicę w adresie między minutą a bullą, a poza tym bulla skierowana do biskupa wileńskiego nie miałaby sensu. ${ }^{36}$ Ekspedycja bulli, mimo zmiany urzędu zajmowanego przez jej odbiorcę byłaby możliwa, gdyby przedmiotem bulli była łaska nie związana z aktualnie piastowaną godnością, jak np. prawo do używania ołtarza przenośnego. Wtedy zmianę tytulatury zasygnalizowano by sformułowaniem: „nunc Wilnensis, tunc Ceretensis episcopus”.

37 Bull. Pol., t. 3, nr 370.

38 W. Abraham, Biskupstwa łacińskie, s. 183-184; P. Czaplewski, Tytularny episkopat w Polsce średniowiecznej (ciag dalszy), „Roczniki Towarzystwa Przyjaciół Nauk Poznańskiego”, t. 43, 1916, s. 74-76; K. Prokop; Biskupi pomocniczy, s. $233-234$.
} 
jako fundatora, było uposażenie nowego biskupstwa. Pierwsze królewskie dokumenty donacyjne pochodzą z lutego 1387 roku $^{39}$. Formalne erygowanie diecezji i powołanie biskupa należało do Stolicy Apostolskiej. Z poselstwem w tej sprawie udał się do Rzymu Dobrogost z Nowego Dworu, biskup poznański i kolektor papieski w Polsce. W odpowiedzi na prośbę pary królewskiej, dnia 12 III 1388 r. papież Urban VI skierował w tej sprawie bullę do Dobrogosta. Nie posiadając sprawdzonych informacji o faktycznym stanie planowanej fundacji („licet de premissis certam noticiam non habeamus”), papież polecił mu zapoznać się z sytuacją. W razie stwierdzenia, że wszystkie konieczne warunki zostały spełnione (chodziło zwłaszcza o uposażenie), nakazał mu erygować mocą władzy apostolskiej biskupstwo w Wilnie. Następnie Dobrogost miał powołać na pierwszego ordynariusza franciszkanina Andrzeja, dotychczasowego biskupa Seretu, dokonując w imieniu papieża jego translacji do Wilna. Ponadto kolektor winien był odebrać od nowego biskupa litewskiego zwyczajową przysięgę, a jej tekst, potwierdzony pieczęcią Andrzeja, przesłać do Rzymu ${ }^{40}$. Sformułowania użyte w bulli wyraźnie wskazują, że to dopiero biskup poznański miał dokonać powyższych czynności prawnych, działając mocą papieskiej władzy. Mogło się to stać dopiero po dłuższym czasie od daty wystawienia papieskiego dokumentu, potrzebnym na dowiezienie bulli do Polski i po spełnieniu papieskich poleceń. Tak więc bulli Urbana VI nie można uznać za oficjalny dokument erekcyjny. Pismo papieskie zostało skierowane do Dobrogosta, a nie do arcybiskupa gnieźnieńskiego, gdyż pełniący funkcję kolektora biskup poznański był jedynym stałym przedstawicielem Stolicy Apostolskiej w Polsce. Oryginalna bulla zapewne pozostała w posiadaniu Dobrogosta, a potem mogła trafić do archiwum katedry poznańskiej. W Wilnie posiadano tylko jej kopię, w formie opisanego niżej insertu ${ }^{41}$.

Kolejnym źródłem dotyczącym objęcia biskupstwa wileńskiego przez Andrzeja Jastrzębca jest niedatowane pismo Dobrogosta $\mathrm{z}$ Nowego Dworu, powszechnie uznawane w historiografii za egzekucję powyższej bulli Urbana VI. Biskup poznański, kierując swój „dokument” do wiadomości wszystkich wiernych, najpierw przytoczył pełny tekst bulli z 12 III 1388 r. Następnie auctoritate apostolica powołał do życia wileńską kapitułę katedralną, kościół p.w. Najświętszej Trójcy, Panny Marii, św. Stanisława i św. Władysława ustanowił katedrą oraz dokonał translacji do Wilna Andrzeja Jastrzębca, dotychczasowego biskupa mołdawskiego ${ }^{42}$. Na końcu wezwał nowego ordynariusza, by dobrze troszczył się o powierzonych mu diecezjan. Pismo kończy się formułą błogosławieństwa: „... in gloria sempiterna, ad quam nos perducat Pater et Filius et Spiritus Sanctus amen”.

Jak wspomniałem, powyższy akt jest pozbawiony daty, ale wydawcy Kodeksu dylomatycznego katedry i diecezji wileńskiej stwierdzili, iż łatwo można ustalić, że pochodzi on z drugiej połowy 1388 roku, gdyż Dobrogost wrócił z Rzymu w czerwcu tego roku ${ }^{43}$. W historiografii uznawano za oczywiste i naturalne, że wprowadzenie w życie papieskich poleceń z 12 marca nastąpiło bezpośrednio po przyjeździe biskupa poznańskiego do kraju. $Z$ tego powodu powszechnie przyjmuje się więc drugą połowę 1388 roku za czas kanonicznego utworzenia biskupstwa wileńskiego i objęcia go przez Andrzeja Jastrzębca. Nie spojrzano jednak krytycznie na powyższe źródło, a zwłaszcza nie zwrócono uwagi na jego dziwaczną formę, która nie pozwala nazywać go dokumentem.

Pierwsza część pisma Dobrogosta ma postać „,normalnego” dokumentu, aż do zapisu o translacji Andrzeja Jastrzębca, po czym następuje dość niezwykła zmiana. Do tej pory wystawca zwracał się

${ }^{39}$ KDWil, nr 1, 6, zob. też nr 2, 3.

40 KDWil, nr 10.

${ }^{41}$ Oryginał bulli nie zachował się. Jej treść znana jest wyłącznie z insertu w piśmie Dobrogosta z Nowego Dworu.

${ }^{42} \mathrm{~W}$ tekście użyte są czasowniki w formie wskazującej, że to sam Dobrogost dokonał właściwej czynności prawnej („erigimus”, ,preficimus”), a nie jedynie potwierdził to, czego papież dokonał już wcześniej.

${ }^{43}$ KDWil, s. 25-26. Ze spisu wydatków Dobrogosta podczas sprawowania urzędu kolektorskiego wiadomo, że wrócił on do kraju z kurii rzymskiej w czerwcu 1388 r. i nieco później podążył za królem na Litwę, zob. J. Korytkowski, Arcybiskupi gnieźnieńscy, prymasowie i metropolici polscy od roku 1000 aż do roku 1821..., t. 1, Poznań 1888, s. 748. Niewątpliwie, po powrocie z Rzymu Dobrogost musiał udać się do króla, by zdać relację z poselstwa. Z itinerarium Jagiełły wynika jednak, że król przebywał na Litwie właściwej dopiero w ostatnim kwartale 1388 r., zob. A. Gąsiorowski, Itinerarium króla Władystawa Jagietty 1386-1434, Warszawa 1972, s. 32. 
do wszystkich wiernych, a w ostatnim zdaniu wspomniał o Andrzeju Jastrzębcu w trzeciej osobie, po czym nagle, w tym samym zdaniu, zwrócił się do samego Andrzeja: „— — nos — — Andream Cerethensem episcopum auctoritate apostolica — — a iugo ecclesie Cerethensis absolventes, vos [czyli „Andream"] predicte ecclesie Vilnensi preficimus in episcopum [et] pastorem”. Nie można przyjąć, że mamy tu do czynienia tylko z błędem kopisty, gdyż następne zdanie Dobrogost kieruje już wprost do Andrzeja: „Studeatis igitur, frater carissime, _ _ ”44. „Dokument” biskupa poznańskiego pozbawiony jest zupełnie eschatokołu, a więc daty, listy świadków, formuły koroboracyjnej. Najbardziej uderzający jest brak daty, co w przypadku dokumentu kościelnego z końca XIV wieku nie mogło mieć miejsca. Warto przy tym pamiętać, że wystawca pisma był doktorem dekretów, więc nie można go posądzić o ignorancję w tej kwestii. Nie trzeba też koniecznie przyjmować, że powyższy akt został wydany w Wilnie. W samym ,dokumencie" nie ma wzmianki o miejscu jego wystawienia, a z punktu widzenia prawa osobista obecność egzekutora bulli w nowokreowanej katedrze nie była niezbędna. Wystarczyło, by nowy biskup pojawił się w Wilnie z ważną prowizją. W przypadku Andrzeja Jastrzębca nie była nawet potrzebna konsekracja, gdyż od niemal 20 lat był on już biskupem. Całe pismo wygląda tak, jakby było sklejone z dwóch części: dokumentu (część początkowa) i czegoś na kształt listu Dobrogosta do Andrzeja Jastrzębca (część końcowa).

Powyższe pismo znane jest z licznych kopii, sporządzonych w XVI-XIX w., w tym wielu na podstawie oryginału. Oryginał nie zachował się, choć podobno znajdował się w archiwum kapituły wileńskiej jeszcze w początkach XIX wieku. Według dawnych opisów, był spisany na pergaminie, opatrzony pieczęcią i nie posiadał daty. Nie ma wzmianki o żadnych uszkodzeniach, które mogłyby być powodem tego braku ${ }^{45}$. Wobec zaginięcia oryginału nie da się stwierdzić, jaka pieczęć była przy nim przywieszona. Z podanych wyżej powodów można wątpić, by było to sigillum wystawcy, biskupa poznańskiego. Nie wiadomo, czym właściwie była pierwsza część omawianego pisma. Może był to wstępnie przygotowany dokument z egzekucją postanowień papieskich, który w odpowiednim momencie należało uzupełnić o listę świadków, datę i koroborację, czego jednak nie uczyniono? Z braku innych dokumentów pismo Dobrogosta, a zwłaszcza inserowana w nim bulla Urbana VI z 12 III 1388 r., było traktowane przez kapitułę katedralną jako akt fundacyjny biskupstwa i samej kapituły. Być może z tego powodu do pergaminu, czymkolwiek by on był, przywiesił swoją pieczęć któryś z późniejszych biskupów wileńskich lub tamtejsza kapituła ${ }^{46}$.

Na koniec trzeba jeszcze wspomnieć o relacji Jana Długosza. W swoich „Rocznikach” odnotował on powstanie biskupstwa wileńskiego pod rokiem $1387^{47}$. Nie wiadomo, skąd pochodziły jego informacje. Można przypuszczać, że wielki dziejopis, który nigdy sam nie był w Wilnie ${ }^{48}$, swoim zwyczajem poprosił kogoś o poszukanie stosownych informacji w archiwum litewskiej katedry. Zapewne asumpt do przyjęcia roku 1387 dały dokumenty fundacyjne Władysława Jagiełły. Długosz najwyraź-

\footnotetext{
${ }^{44}$ Ciekawe, że dawniejsi historiografowie biskupstwa wileńskiego traktowali końcową część pisma Dobrogosta jako słowa, którymi biskup poznański zwrócił się do Andrzeja Jastrzębca podczas wprowadzania go na katedrę, zob. W. Przyałgowski, Żywoty biskupów wileńskich, Petersburg 1860, t. 1, s, 14; J. Kurczewski, Biskupstwo wileńskie od jego założenia aż do dni obecnych..., Wilno 1912, s. 23.

${ }^{45}$ KDWil, s. 24-25.

46 Jak sądzę, możliwe jest jeszcze inne wyjaśnienie powstania pergaminowego „oryginału” pisma Dobrogosta z Nowego Dworu. Być może pierwsza część tekstu (spisana na papierze) była minutą dokumentu egzekucyjnego papieskiej bulli z 12 III 1388 r., pozbawioną formuł eschatokołu, a towarzyszył jej list Dobrogosta (również papierowy) do Andrzeja Jastrzębca, z zachętą do dobrego wypełniania obowiązków duszpasterskich. W późniejszym czasie, z powodu braku dokumentu fundacyjnego diecezji, biskup lub kapituła mogli zlecić przepisanie powyższych tekstów na pergaminie, w celu przechowania dla potomnych informacji o utworzeniu biskupstwa, a sporządzony odpis opatrzono pieczęcią dla potwierdzenia jego wiarygodności. Przy okazji kopiowania mogło dojść do zlania się obu fragmentów w jedną, bardzo niespójną całość. ${ }^{47}$ Joannis Dlugossii Annales seu cronicae incliti Regni Poloniae, lib. 10 (1370-1405), Varsaviae 1985, s. $162-163$.

${ }^{48}$ Zob. M. Bobrzyński, S. Smolka, Jan Dtugosz. Jego życie i stanowisko w piśmiennictwie, Kraków 1893; A. Perzanowska: Wiadomości źródłowe o życiu i działalności Jana Dlugosza, w: Dlugossiana. Studia historyczne w pięćsetlecie śmierci Jana Długosza, red. S. Gawęda. Warszawa 1980, Zeszyty Naukowe Uniwersytetu Jagiellońskiego. Prace Historyczne, z. 65, s. $293-365$.
} 
niej nie znał bulli z 12 III 1388 roku, a konsekrację katedry przypisał arcybiskupowi Bodzęcie, a nie Dobrogostowi z Nowego Dworu.

Ponadto średniowieczny historyk podał jeszcze jeden, niezwykle ciekawy szczegół. Napisał mianowicie, iż ze względu na ubóstwo swoich dóbr stołowych biskup Andrzej otrzymał (od króla), jako dodatkowe uposażenie, kościół parafialny w Kłodawie. Wyraźnie koresponduje to z treścią bulli, będącej przedmiotem niniejszego artykułu. Kumulowanie wraz biskupstwem dodatkowego beneficjum niższego nie mogło być oczywiście decyzją króla, ale potrzebna była dyspensa papieska. Jak sądzę, jest wysoce prawdopodobne, że domniemany informator Długosza miał w ręku wspomnianą w dokumencie Bonifacego IX (z 9 XI 1389 r.) bullę sprzed 20 II 1386 r., według której biskup Andrzej kumulował z biskupstwem w Serecie kościół w Kłodawie ${ }^{49}$. Podczas redagowania „Roczników” dziejopis łatwo mógł pomyłkowo odnieść tę dyspensę do biskupstwa wileńskiego, zamiast do sereckiego. Źródłem pomyłki mógł też być informator Długosza, zwłaszcza gdyby niezbyt starannie zapoznał się z bullą papieską ${ }^{50}$. Poza tym można powątpiewać, czy Jastrzębiec — jako ordynariusz wileński - zabiegałby o zgodę na dodatkowe uposażenie. Nie wiadomo wprawdzie, jak duży był majątek biskupstwa wileńskiego w momencie jego kanonicznej erekcji i czy pierwszy biskup potrzebował dodatkowych dochodów ${ }^{51}$, ale ewentualna prośba do Stolicy Apostolskiej, motywowana ubóstwem biskupstwa, stałaby w sprzeczności z zapewnieniami królewskimi o wystarczającym uposażeniu litewskiej katedry.

W świetle powyższych uwag można stwierdzić, iż nie da się wykazać źródłowo, że biskupstwo w Wilnie erygowano kanonicznie w 1388 roku. Bulla Urbana VI z 12 marca t.r. była od wieków traktowana $\mathrm{w}$ środowisku katedry wileńskiej jak dokument fundacyjny, ze względu na zaskakujący brak właściwego aktu prawnego. Nie był nim na pewno „dokument” egzekucyjny Dobrogosta z Nowego Dworu. W znanych obecnie źródłach Andrzej Jastrzębiec pojawia się jako biskup wileński dopiero 30 VIII 1391 r. ${ }^{52}$ Gdy w drugiej połowie 1390 roku ekspediowano bullę Bonifacego IX z 9 XI 1389 r., Andrzej Jastrzębiec mógł być jeszcze wciąż biskupem Seretu. Charakterystyczne jest, że w dokumencie Władysława Jagiełły z 10 I 1389 r., dotyczącym uprawnień biskupa, żaden konkretny hierarcha nie został wymieniony ${ }^{53}$.

Komentarza wymaga jeszcze przywilej królewski z dnia 15 V 1390 r., powiększający uposażenie kapituły katedralnej, gdzie wspomniana jest „ecclesia nostra cathedralis Vilnensis (...) nuper erecta et eius capitulum"54. Choć dokument ów nosi datę nieco wcześniejszą, niż moment wyekspediowania bulli Bonifacego IX (najwcześniej po $30 \mathrm{~V} 1390$ r.), to nie ma w tym sprzeczności. Uwzględniając czas trwania podróży z Litwy lub z Wielkopolski, gdzie Andrzej Jastrzębiec był sufraganem, do Rzymu, oraz czas potrzebny na załatwienie sprawy w kancelarii papieskiej można przyjąć, że pełnomocnik biskupa Andrzeja wyruszył w drogę przynajmniej 2 miesiące przed datą ekspedycji bulli, a więc nawet na przełomie marca i kwietnia. Gdyby fundacja diecezji wileńskiej nastąpiła wkrótce potem, nie powstrzymałoby to już wystawienia papieskiego dokumentu adresowanego do biskupa Seretu. Promocję Jastrzębca na litewskiego ordynariusza należałoby w takim przypadku kłaść na kwiecień lub pierwszą połowę maja, zamiast na drugą połowę 1390 roku lub pierwszą połowę roku następnego. Wydaje się jednak, że przesuwanie kanonicznej erekcji biskupstwa w Wilnie przed połowę maja 1390 r. nie jest konieczne. Data 15 V 1390 r. mogła odnosić się do akcji prawnej, ale sam dokument

\footnotetext{
49 Zob. uwagi powyżej oraz tekst bulli Bonifacego IX publikowany na końcu artykułu.

${ }^{50} \mathrm{Na}$ zewnętrznej stronie złożonego dokumentu często już w średniowieczu pisano krótką notę o jego treści. O pomyłkę byłoby wyjątkowo łatwo, gdyby informator Długosza zadowolił się tylko przeczytaniem takiej noty.

${ }_{51}$ J. Ochmański, Biskupstwo wileńskie w średniowieczu. Ustrój i uposażenie, Poznań 1972, s. 95-99.

${ }^{52} \mathrm{KDW}$ il, nr 21. Z tytułem biskupa wileńskiego Andrzej pojawia się wprawdzie już na liście świadków dokumentu Władysława Jagiełły z 1 VI 1387 r., ale z pewnością nie był jeszcze wtedy legalnym posiadaczem tej godności. Sami wydawcy dokumentu określili go, jako „naonczas nominata królewskiego”, zob. KDWil, nr 9.

${ }_{53}$ KDWil, nr 15.

${ }^{54}$ KDWil, nr 17.
} 
mógł zostać spisany nawet kilka miesięcy później i użyte sformułowanie „ecclesia cathedralis Vilnensis" oddawało już późniejszy, zmieniony stan faktyczny, gdy kościół w stolicy Litwy rzeczywiście był katedrą. Warto zauważyć, że choć przywilej Jagiełły dotyczy kapituły i wystawiony został w Wilnie, w jego tekście nie ma żadnej wzmianki o biskupie, a na liście świadków nie ma żadnego prałata czy kanonika wileńskiego ${ }^{55}$.

Rodzą się oczywiście pytania o to, dlaczego Andrzej nie zadbał o wystawienie bulli z dyspensą na kumulację beneficjów w 1386 roku i dlaczego postarał się o to ponad 4 lata później? Być może wiosną 1386 r. zrezygnował z ponoszenia kosztów ekspedycji dokumentu papieskiego właśnie dlatego, że pojawiła się perspektywa rychłego przejścia do Wilna. Mimo zgody papieskiej, wyrażonej 12 III 1388 r., z nieznanych powodów sprawa znacznie się przeciągnęła. Trudno powiedzieć, co mogło być przyczyną dwuletniej zwłoki. Być może pojawił się inny kandydat do biskupstwa, może początkowe uposażenie biskupstwa lub kapituły zostało uznane za niewystarczające albo też pojawiły się problemy co do podległości administracyjnej nowej diecezji. Prawdopodobnie właśnie przeciągające się oczekiwanie na objęcie katedry spowodowało, iż biskup Seretu, faktycznie będący wciąż gnieźnieńskim biskupem pomocniczym, zdecydował się poprosić o wyekspediowanie bulli z dyspensą, która dawała mu możliwość zwiększenia niedużego uposażenia, jakie dotąd posiadał.

Można więc wysunąć ostrożną hipotezę, że kanonicznej erekcji biskupstwa wileńskiego i translacji biskupa Andrzeja h. Jastrzębiec z Seretu do Wilna dokonano dwa lata później, niż dotąd sądzono, dopiero około połowy 1390 roku, lub nawet w pierwszej połowie 1391 roku. Zapewne kłóci się to z intuicyjnym odczuciem, że fundacja ta powinna dojść do skutku bezpośrednio po tym, jak Dobrogost z Nowego Dworu wrócił z poselstwa do Rzymu, ale w świetle dostępnych dziś źródeł przesunięcie daty powstania pierwszej diecezji litewskiej wydaje się uzasadnione.

\section{Aneks}

Edycja stosuje reguły wydawnicze określone przez: Instrukcja wydawnicza dla średniowiecznych źródet historycznych, oprac. Komisja Historyczna Polskiej Akademii Umiejętności, Kraków 1925.

Rzym, 9 listopada 1389 r. (suplika z 20 lutego 1386 r.)

Bonifacy IX potwierdza zgode papieża Urbana VI z dnia 20 II 1386 r. na dokonanie korekty w bulli wystawionej niegdyś dla Andrzeja, biskupa Seretu.

kopia: ASV, Reg. Lat., vol. 2463, f. 2r; vol. 5, f. 10r-10v

uwaga: Tekst kilku poczatkowych wierszy niniejszego dokumentu, znajdujących się na karcie $2 r$ w tomie Reg. Lat., vol. 2463, został już podany (bez daty) w dwóch wydawnictwach źródtowych: 1. MPV, t. 8, nr 85; 2. Bull. Pol., t. 3, nr 398.

/RL 2463, f. 2r/ Bonifacius etc., venerabili fratri Andree, episcopo Ceretensi, salutem etc. Racioni congruit etc. Dudum siquidem felicis recordacionis Urbanus papa VI, predecessor noster, tecum, qui - ut asserebatur - de fructibus et redditibus tue mense episcopalis Ceretensis commode sustentari non poteras, cum omnia bona dicte mense per infideles Littuanos penitus essent consumpta et

\footnotetext{
${ }^{55}$ Można też dopuścić możliwość, że słowa o niedawno erygowanej katedrze nie odnoszą się do podniesienia wileńskiej świątyni do rangi katedry, ale dotyczą założenia tego kościoła, co stało się zaledwie kilka lat wcześniej. Już w dokumencie z 1387 r. król zapowiadał, że ufundowany w Wilnie kościół stanie się wkrótce katedrą biskupią, por. KDWil, nr 1. Trudno jest z absolutną pewnością wypowiedzieć się na temat autentyczności nadania królewskiego z $15 \mathrm{~V} 1390$ r., a zwłaszcza jego daty. Dokument znany jest wyłącznie z transumptu Zygmunta Starego z grudnia 1518 r. (zob. KDWil, s. 30-31). Archiwum kapituły wileńskiej posiadało dokumenty, uznane przez wydawców za podrobione lub podejrzane (por. KDWil, nr 8, 14, 20), więc może i w przypadku przywileju z 15 V 1390 r. mamy do czynienia z antydatowanym nadaniem monarszym.
} 
deserta, et quia dudum in illis partibus processus per ipsum predecessorem factos contra perdicionis alumnum Robertum, olim ${ }^{a}$ Basilice XII Apostolorum presbyterum cardinalem, tunc et nunc antipapam, qui se Clementem VII ausu sacri/RL 5, f. 10r/lego nominare presumebat et presumit, publicaveras et eciam quosdam principes et alios illarum parcium olim infideles cum trecentis aliis personis, eciam infidelibus, ad fidem catholicam conversos baptizaveras et cum quo dudum, ut parrochialem ecclesiam in Clodavva, Gneznensis diocesis, cuius fructus, redditus et proventus sexaginta florenorum auri secundum taxacionem decime valorem annuum - ut asserebatur — non excedebant, una cum dicta tua Ceretensi ecclesia libere recipere et licite retinere valeres, extiterat auctoritate apostolica dispensatum, ut unum aliud beneficium ecclesiasticum cum cura vel sine cura, eciam si canonicatus et prebenda aut dignitas, personatus vel officium in cathedrali vel collegiata ecclesiis foret, dummodo huiusmodi dignitas in cathedrali maior post pontificalem vel in collegiata ecclesiis huiusmodi principalis non foret, et assumereris ad illud vel alias tibi canonice conferretur, libere recipere et una cum Ceretensi et parrochiali ecclesiis predictis licite retinere valeres, auctoritate predicta dispensavit, prout in ipsius predecessoris litteris inde confectis ${ }^{\mathrm{b}}$ plenius continetur. Postmodum vero pro parte tua exposito predicto predecessori, quod in dictis litteris per errorem expressum fuerat, quod tecum, ut dictam parrochialem ecclesiam una cum dicta Ceretensi ecclesia retinere posses, extiterat auctoritate predicta dispensatum, cum re vera non sic fuisset, sed tecum dispensatum fuerat, ut preposituram ecclesie in Kalis, dicte diocesis, que dignitas principalis in eadem ecclesia existebat cuiusque fructus, redditus et proventus predictum valorem secundum eandem extimacionem non excedebant, una cum prefata ecclesia Ceretensi retinere valeres, fuisset auctoritate predicta dispensatum ac pro parte tua eidem predecessori supplicato, ut super hoc tibi de oportuno remedio providere dignaremur. Idem ${ }^{\mathrm{c}}$ predecessor voluit et auctoritate apostolica concessit, videlicet $\mathrm{X}$ kal. marcii pontificatus sui anno octavo [=20 II 1386], ut predicte littere et quecumque inde secuta perinde a dicta die, videlicet X kal. marcii ${ }^{\mathrm{d}}$, valerent et plenam obtinerent roboris firmitatem, acsi in eis fuisset expressum, quod tecum ut dictam preposituram una cum prefata ecclesia Ceretensi retinere valeres, auctoritate predicta dispensatum extitisset. Ne autem pro eo, quod super huiusmodi voluntate et concessione dicti predecessoris littere confecte minime extiterunt, huiusmodi voluntatis et concessionis frustreris effectu, volumus et apostolica auctoritate decernimus, quod huiusmodi voluntas et concessio predecessoris eiusdem perinde a dicta die, videlicet $\mathrm{X}$ kal. marcii, suum consequantur effectum acsi super eis predicti predecessoris littere sub eiusdem diei data confecte fuissent, prout superius enarratur, quodque presentes littere /RL 5, f. 10v/ ad probandum plene voluntatem et concessionem predictas ubique sufficiant nec ad id probacionis alterius ${ }^{e}$ adminiculum requiratur. Nulli ergo etc. nostre voluntatis et constitucionis infringere etc. Si quis autem etc. Datum Rome apud Sanctum Petrum, quinto idus novembris, anno primo. N(icolaus). XX. de Benevento.

\footnotetext{
a Słowo poprzedzone przez skreślone: „obm”.

b Słowa: ,inde confectis” dopisane na prawym marginesie, z zaznaczeniem miejsca wstawienia.

"Słowo poprzedzone przez skreślone: „iden”.

d Data korygowanej bulli najpewniej została tu pomylona przez pisarza, powinna być bowiem wcześniejsza niż 20 II 1386 r., czyli data supliki o korektę plebanii w Kłodawie na prepozyturę kaliską.

e Słowo poprzedzone przez skreślone: ,alteu”.
} 


\section{An Unknown Papal Document Issued to Andrzej, First Bishop of Seret and Wilno, and the Foundation of the Wilno Bishopric}

Papal chancery registers in the Registra Lateranensia series include a bull issued by Boniface IX, addressed to Andrzej Jastrzębiec, the first Catholic bishop of Seret (Moldavia), and heretofore unexamined by historians. The "Rationi congruit" type bull features the date 9 November 1389, but was issued by the papal chancery in the second half of 1390 (after 30 May). In it, the pope expressed his consent for Andrzej to cumulate two lower benefices together with the indigent bishopric of Moldavia. A pertinent supplication had been considered by Urban VI already on 20 February 1386, but the supplicant succeeded in having the bull dispatched four years later, already during the successor's pontificate. Historians agree that Andrzej Jastrzębiec was the first bishop of Wilno as early as the middle of 1388, an opinion negated by the titles used in the document. Sources concerning the beginnings of the Wilno bishopric are extremely scarce. The bishopric lacks a foundation act and the opinion about the establishment of a Lithuanian diocese in the middle of 1388 is based on an undated letter by the Bishop of Poznań Dobrogost of Nowy Dwór, whom the pope supposedly commissioned to perform its canonical erection. This letter, known solely as a copy devoid of a date and an eschatocol, and featuring a curious grammatical form, cannot be recognised as a document and does not provide foundations for determining the time of the origin of the bishopric and the translatio of Andrzej from Seret to Wilno. Jastrzębiec does not appear in preserved sources with the title of the bishop of Wilno until 30 August 1391. The bull issued by Boniface IX thus imposes the acknowledgement that the foundation of a bishopric in the capital of Lithuania took place either in the second half of 1390 or in the first half of the following year, i.e. two years later than has been assumed until now. The reasons for such a long delay in creating a diocese in Lithuania still remain unclear.

Kontakt do autora: marek_daniel.kowalski@uj.edu.pl 